\title{
Crystal structure of samarium nickel tetraaluminide, $\mathrm{SmNiAl}_{4}$
}

\author{
M. L. Fornasini*.I, R. Raggio ${ }^{\text {Il }}$ and G. Borzone ${ }^{1}$ \\ I Università di Genova. Dipartimento di Chimica e Chimica Industriale, Via Dodecaneso 31, I-16146 Genova, Italy \\ " Università di Genova, Dipartimento di Scienze Farmaceutiche. Viale Benedetto XV 3, I-16132 Genova, Italy
}

Received March 3, 2004, accepted and available on-line April 22, 2004; CSD no. 409776

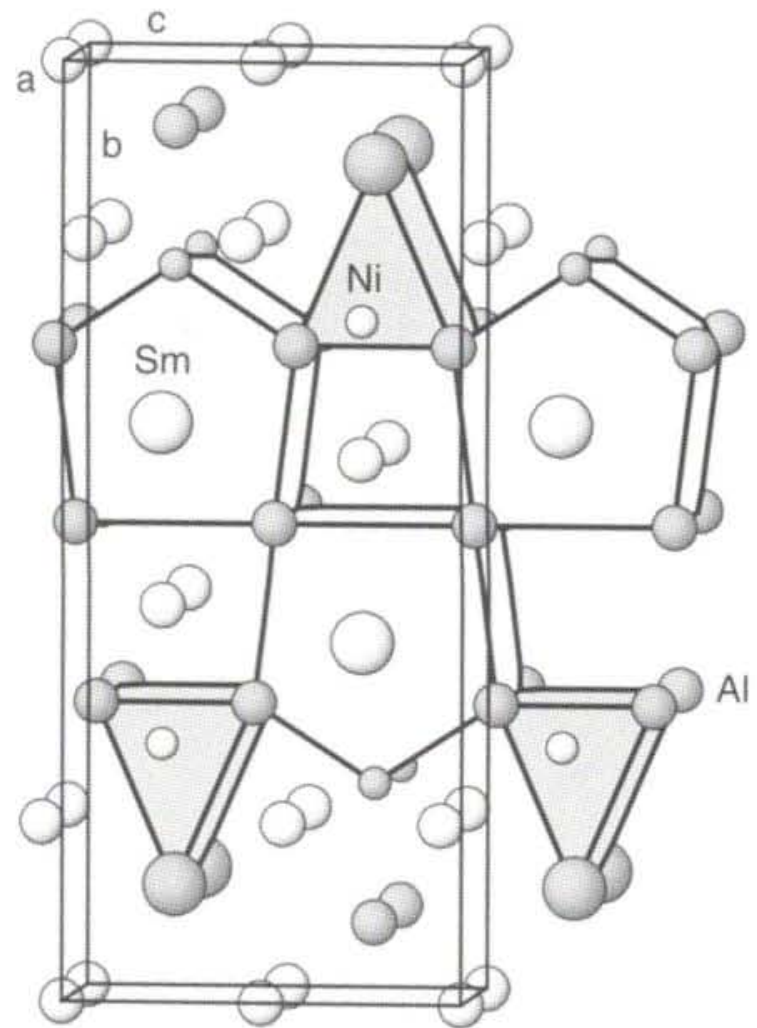

Abstract

$\mathrm{Al}_{4} \mathrm{NiSm}$, orthorhombic, $\mathrm{Cmcm}$ (no. 63), $a=4.0948(6) \AA$, $b=15.582(3) \AA, c=6.610(1) \AA, V=421.8 \AA^{3}, Z=4$, $R_{\mathrm{gt}}(F)=0.028, w R_{\mathrm{obs}}\left(F^{2}\right)=0.074, T=293 \mathrm{~K}$.

\section{Source of material}

The metals used were $\mathrm{Sm}$ ( 99.9 wt.\%), $\mathrm{Ni}$ and $\mathrm{Al}$ ( 99.999 wt.\%). The samples, each with a total weight of $1-1.5 \mathrm{~g}$, were prepared by induction melting of the components in alumina crucibles un-

der an argon flow. In order to attain proper homogenization the samples were remelted several times under continuous shaking. The alloys were then annealed at $773 \mathrm{~K}$ for 15 days and finally water quenched.

\section{Discussion}

A recent investigation of the phase relations in the ternary system $\mathrm{Sm}-\mathrm{Ni}-\mathrm{Al}$ at $773 \mathrm{~K}$ [1] revealed the formation of four new ternary compounds, namely $\mathrm{SmNiAl}_{4}, \mathrm{Sm}_{4} \mathrm{Ni}_{6} \mathrm{Al}_{23}, \mathrm{SmNiAl}_{3}$ and $\mathrm{SmNi}_{2} \mathrm{Al}_{3}$. The compound $\mathrm{SmNiAl}_{4}$ (Pearson code oS24) was found to be isotypic with $\mathrm{YNiAl}_{4}$ [2]. The $\mathrm{Ni}$ atom is surrounded by a trigonal prism formed by $2 \mathrm{Sm}+4 \mathrm{Al}$ capped on each lateral face by three other $\mathrm{Al}$ atoms. The $\mathrm{Sm}$ atom is at the centre of a pentagonal prism formed by $8 \mathrm{Al}+2 \mathrm{Ni}$ with all lateral faces capped by aluminium atoms. These polyhedra are highlighted in the figure. The $\mathrm{Ni}-\mathrm{Al}$ distances are the shortest ones, reaching with 2.297 (4) $\AA$ a $14.2 \%$ contraction with respect to the sum of the metallic radii for $C N 12$ [3], while contractions of $8.9 \%$ and $6.5 \%$ are found for 2.608(4) $\AA \mathrm{Al}-\mathrm{Al}$ and 3.023(3) $\AA \mathrm{Sm}-\mathrm{Al}$ contacts, respectively. On the contrary, the $\mathrm{Sm}-\mathrm{Ni}$ distances are about $5 \%$ greater than the sum of the metallic radii.

Table 1. Data collection and handling.

\section{Crystal:}

Wavelength:

$\mu$ :

Diffractometer, scan mode:

$2 \theta_{\max }$ :

$N(h k l)_{\text {measured, }} N(h k l)_{\text {unique: }}$

Criterion for $I_{\mathrm{obs}}, N(h k l)_{\mathrm{gl}}$ :

$N(\text { param })_{\text {refined: }}$

Programs:

\section{silver luster prism,}

size $0.04 \times 0.12 \times 0.13 \mathrm{~mm}$

Mo $K_{\alpha}$ radiation $(0.71070 \AA)$

$188.60 \mathrm{~cm}^{-1}$

Bruker-Nonius MACH3, $\omega-\theta$

$59.8^{\circ}$

747,374

$I_{\text {obs }}>2 \sigma\left(I_{o b s}\right), 354$

23

SHELXI-97 [4], ATOMS [5]

Table 2. Atomic coordinates and displacement parameters (in $\AA^{2}$ ).

\begin{tabular}{lllllllllll}
\hline Atom & Site & $x$ & $y$ & $z$ & $U_{11}$ & $U_{22}$ & $U_{33}$ & $U_{12}$ & $U_{13}$ & $U_{23}$ \\
\hline $\mathrm{Sm}$ & $4 c$ & 0 & $0.38404(3)$ & $1 / 4$ & $0.0068(3)$ & $0.0031(3)$ & $0.0070(3)$ & 0 & 0 & 0 \\
$\mathrm{Ni}$ & $4 c$ & 0 & $0.72547(8)$ & $1 / 4$ & $0.0065(6)$ & $0.0045(5)$ & $0.0064(5)$ & 0 & 0 & 0 \\
$\mathrm{Al}(1)$ & $8 f$ & 0 & $0.1900(1)$ & $0.0527(3)$ & $0.009(1)$ & $0.0070(9)$ & $0.0049(9)$ & 0 & 0 & $0.0001(7)$ \\
$\mathrm{Al}(2)$ & $4 c$ & 0 & $0.5780(2)$ & $1 / 4$ & $0.013(2)$ & $0.005(1)$ & $0.012(1)$ & 0 & 0 & 0 \\
$\mathrm{Al}(3)$ & $4 a$ & 0 & 0 & 0 & $0.012(1)$ & $0.006(1)$ & $0.013(1)$ & 0 & 0 & $0.002(1)$ \\
\hline
\end{tabular}

\footnotetext{
* Correspondence author (e-mail: cfmet@chimica.unige.it)
} 


\section{References}

1. Borzone, G.; Raggio, R.; Delsante. S.; Ferro, R.: Phase equilibria in the Sm-Ni-Al alloy system. Submitted to Intermetallics.

2. Rykhal', R. M.; Zarechnyuk, O. S.; Yarmolyuk, Ya. P.: Crystal structure of the compounds $\mathrm{YNiAl}_{4}$ and $\mathrm{YNiAl}_{2}$. Sov. Phys. Crystallogr. 17 (1972) 453-455.

3. Teatum, E.; Gschneidner Jr., K. A.; Waber, J.: Rep. LA-4003. National Technical Information Service, Springfield, VA, USA 1968.

4. Sheldrick, G. M.: SHELXL-97. Program for the Refinement of Crystal Structures. University of Göttingen. Germany 1997.

5. Dowty, E.: ATOMS. Version 5.1 for Windows. Program for Displaying Atomic Structures. Shape Software, Kingsport TN, USA 2000. 